\title{
Cerebral Cortical Tissue Damage After Hemorrhagic Hypotension in Near-Term Born Lambs
}

\author{
SANDRA VAN OS, EVELYN VAN DEN TWEEL, HANS EGBERTS, JEROEN HOPMAN, WIM RUITENBEEK, FRANK VAN BEL, \\ FLORIS GROENENDAAL, AND MARGOT VAN DE BOR
}

\begin{abstract}
Department of Pediatrics [S.O., J.H., W.R., M.B.], Radboud University Nijmegen Medical Center, 6500 HB Nijmegen, The Netherlands, Department of Neonatology and Psychoneuroimmunology Laboratory [E.T., F.B., F.G.], University Medical Center Utrecht, 3508 AB Utrecht, The Netherlands, Department of Obstetrics and Gynecology [H.E.], Leiden University Medical Center, 2300 RC, Leiden, The Netherlands
\end{abstract}

\begin{abstract}
Hypotension reduces cerebral $\mathrm{O}_{2}$ supply, which may result in brain cell damage and loss of brain cell function in the near-term neonate. The aim is to elucidate 1) to what extent the functional disturbance of the cerebral cortex, as measured with electrocortical brain activity (ECBA), is related to cerebral cortical tissue damage, as estimated by MAP2; and 2) whether there is a relationship between the glutamate, nitric oxide (NO), cGMP pathway and the development of cerebral cortical tissue damage after hemorrhagic hypotension. Seven lambs were delivered at $131 \mathrm{~d}$ of gestation. Hypotension was induced by withdrawal of blood until mean arterial blood pressure was reduced to $30 \%$ of normotension. Cerebral $\mathrm{O}_{2}$ supply, consumption, and ECBA were calculated in normotensive conditions and after $2.5 \mathrm{~h}$ of hypotension. Concentrations of glutamate and aspartate in cerebrospinal fluid (CSF), $\mathrm{NO}_{2}$ and $\mathrm{NO}_{3}(\mathrm{NOx})$ in plasma, and cGMP in cortical brain tissue were determined in both conditions. CSF and brain tissue from siblings were used to determine normotensive values. Cortical neuronal damage was detected after $2.5 \mathrm{~h}$ of hypotension. ECBA was negatively related to the severity of the cortical damage. ECBA was related to respectively glutamate, NOx, and cGMP concentrations. In conclusion, cortical neuronal damage is detected after $2.5 \mathrm{~h}$ of hemorrhagic hypotension in the near-term born lamb. The damage is reflected by a reduction of ECBA. The glutamate, NOx, cGMP pathway is likely to be involved in the pathogenesis of cerebral cortical damage. (Pediatr Res 59: 221-226, 2006)
\end{abstract}

$\mathrm{T}$ he developing brain requires an adequate supply of oxygen and substrates for function and growth. In immature newborns, cerebral oxygenation and hemodynamics are easily disturbed because of the immaturity of various organ systems, e.g. pulmonary and cardiovascular systems. Sufficient cerebral $\mathrm{O}_{2}$ supply is therefore frequently jeopardized in those infants. Hypotension may diminish or disrupt the cerebral blood flow (CBF), with a consequent reduction of the supply of oxygen and substrates to the brain, thereby hindering the brain in normal functioning and growth (1).

Neurons are very sensitive to reduced supplies of oxygen and glucose $(2,3)$. Reduced cerebral $\mathrm{O}_{2}$ supply results in a cascade of events. The excess release of excitatory amino

Received March 24, 2005; accepted September 21, 2005.

Correspondence: Margot van de Bor, M.D., Ph.D., Department of Pediatrics 435, Radboud University Nijmegen Medical Center, P.O. Box 9101, 6500 HB Nijmegen, The Netherlands; e-mail: margot.van.de.bor@falw.vu.nl

DOI: 10.1203/01.pdr.0000197308.36252.e8 acids, in particular glutamate, during conditions of energy failure initiates a massive influx of $\mathrm{Ca}^{2+}$ into the cell. The increased intracellular $\mathrm{Ca}^{2+}$ concentration triggers $\mathrm{Ca}^{2+}$ dependent processes (4), such as the formation of NO from L-arginine by nitric oxide synthase (NOS) (5). NO increases the concentrations of cyclic GMP (cGMP) through the activation of soluble guanylate cyclase (sGC) (5). Ultimately, this cascade may lead to brain cell dysfunction and cell death (6).

Whereas brain cell dysfunction can be measured in vivo noninvasively by neurophysiological methods $(7,8)$, brain cell death can only be assessed histologically. Microtubuleassociated proteins (MAP) are a diverse family of cytoskeletal proteins apparently present in all vertebrates including man (9). They perform important functions related to normal neuronal integrity through the maintenance of nerve cell shape and intracellular transport, and to the regulation of neuronal morphogenesis (10). It has been shown that the loss of MAP2 correlates with neuronal degeneration after brain injury in rodents (11). Alteration of the cytoskeleton is a major step in the initiation of apoptosis in several cell types (12).

In a previous study, we demonstrated in near-term lambs that brain cell function deteriorated during hypotension when MABP had been reduced to $30 \%$ of normotension (13). The aim of the present study is to elucidate 1) to what extent the functional disturbance of the cerebral cortex, as measured with ECBA, is related to cerebral cortical tissue damage, as estimated by MAP2 staining after $2.5 \mathrm{~h}$ of hemorrhagic hypotension in lambs born at $131 \mathrm{~d}$ of gestation, and 2) whether there is a relationship between the glutamate, NO, cGMP pathway, and the development of cerebral cortical tissue damage.

\section{METHODS}

The study was approved by the Institutional Animal Care and Use Committee of the University of Nijmegen before implementation.

Animal preparation and instrumentation. Seven pregnant ewes of Dutch Texel breed were operated at $131 \mathrm{~d}$ of gestation (term $147 \mathrm{~d}$ ) under general

Abbreviations: cGMP, cyclic guanosine $3^{\prime}, 5^{\prime}$-monophosphate; CSF, cerebrospinal fluid; ECBA, electrocortical brain activity; MABP, mean arterial blood pressure; MAP2, microtubule-associated protein 2; NO, nitric oxide; NOx, $\mathrm{NO}_{2}$ and $\mathrm{NO}_{3}$; Qcar, flow in left carotid artery; $\mathbf{s G C}$, soluble guanylate cyclase 
anesthesia with $3 \%$ isoflurane. After a polyvinyl catheter was inserted into the jugular vein, isoflurane anesthesia was replaced with infusion of $600 \mathrm{mg} / \mathrm{h}$ ketamine hydrochloride and $15 \mathrm{mg} / \mathrm{h}$ midazolam. A catheter was placed into the left carotid artery for measurement of MABP and blood sampling. The ewe was kept in an optimal ventilatory $\left(\mathrm{PaO}_{2}: 10-15 \mathrm{kPa}, \mathrm{PaCO}_{2}: 4-5 \mathrm{kPa}\right.$; $\mathrm{pH}$ : 7.3-7.4) and circulatory (MABP: $100-120 \mathrm{~mm} \mathrm{Hg}$ ) condition. A pregnant horn of the uterus was exposed, and an incision was made in the uterus over the fetal head. Siblings were kept in utero and were not instrumented. They were used to determine concentrations of glutamate and aspartate in cerebrospinal fluid (CSF) and concentrations of cGMP and MAP2 staining in cerebral cortical tissue during normotension.

The fetus' head and right fore limb were delivered and an occluder was placed around the umbilical cord, but was not clamped yet. A polyvinyl catheter [outer diameter (OD) $2.1 \mathrm{~mm}$ ] was placed in the right brachial vein for administration of ketamine hydrochloride $(10 \mathrm{mg} / \mathrm{kg} / \mathrm{h})$, glucose $5 \%(2$ $\mathrm{mL} / \mathrm{kg} / \mathrm{h}$ ), and a single dose of antibiotics (amoxicillin $50 \mathrm{mg} / \mathrm{kg}$, gentamicin $2.5 \mathrm{mg} / \mathrm{kg}$ ). The right brachial artery (polyvinyl catheter, OD: $2.1 \mathrm{~mm}$, with its catheter tip in the arcus aortae) and right jugular vein (polyurethane catheter, OD: $0.9 \mathrm{~mm}$, in the cranial direction) were cannulated for measurement of the MABP and blood sampling. MABP was measured with disposable transducers (Edwards Life Sciences BV, Los Angeles, CA). Blood gases were analyzed with a blood gas analyzer (ABL 510, Radiometer Medical A/S, Copenhagen, Denmark). Arterial oxygen saturation $\left(\mathrm{SaO}_{2}\right)$ values were corrected for interspecies differences (14).

After exposing the left carotid artery, we applied an appropriately sized perivascular ultrasonic blood flow transducer (2SL, S or B, Transonic System Inc., New York, NY) to assess changes in carotid artery blood flow (Qcar). A close linear relationship between Qcar and CBF was reported by Van Bel et al. (15).

Cerebral $\mathrm{O}_{2}$ supply and $\mathrm{O}_{2}$ consumption were calculated as follows:

$\mathrm{O}_{2}$ supply $\left(\mathrm{mL} \mathrm{O}_{2} / \mathrm{min}\right)=\mathrm{Qcar} \times \mathrm{CaO}_{2}$,

$\mathrm{O}_{2}$ consumption $\left(\mathrm{mL} \mathrm{O}_{2} / \mathrm{min}\right)=\mathrm{Qcar} \times\left(\mathrm{CaO}_{2}-\mathrm{CvO}_{2}\right)$,

with arterial (venous) oxygen content:

$\mathrm{Ca}(\mathrm{v}) \mathrm{O}_{2}\left(\mathrm{~mL} \mathrm{O}_{2} / \mathrm{mL}\right)=$ arterial (venous) $\mathrm{O}_{2}$ saturation $\left(\mathrm{Sa}(\mathrm{v}) \mathrm{O}_{2}\right) \times \mathrm{Hb}$ $(\mathrm{g} / \mathrm{dL}) \times 1.36\left(\left(\mathrm{~mL} \mathrm{O}_{2} / \mathrm{g} \mathrm{Hb}\right) / 100\right)$.

Two disposable subdermal needle electrodes for EEG recordings (Oxford Instruments BV, Gorinchem, The Netherlands) were positioned on the parietal regions of the skull, and one electrode on the occipital region as a reference. ECBA was calculated as the root mean square (RMS) value of a band-filtered $(2-16 \mathrm{~Hz})$, one-channel EEG $(7,8)$, which is comparable with a voltage scale.

Experimental procedures. After preparation, the instrumented lamb was intubated. Ventilation was started using a continuous flow, pressurecontrolled ventilator (Babylog $1 \mathrm{HF}$, Dräger, Lübeck, Germany). Minor adjustments of the ventilator settings were sometimes required to obtain optimal blood gases.

When the instrumented lamb was in an optimal ventilatory $\left(\mathrm{PaO}_{2}: 10-14\right.$ $\mathrm{kPa}$; $\mathrm{PaCO}_{2}$ : 4.5-6.0 kPa; $\mathrm{pH}: 7.3-7.4$ ) and circulatory (MABP 60-65 mm $\mathrm{Hg}$ ) condition, the umbilical cord was clamped to mimic an extrauterine condition. Surfactant (Survanta, Ross Laboratories, Columbus, OH) was administered if necessary to achieve an optimal ventilation and oxygenation with a fraction of inspired oxygen concentration $\left(\mathrm{FiO}_{2}\right)$ of 0.30 .

A stabilization period of three hours was applied. To obtain hypotension, blood was withdrawn in a stepwise manner until MABP had dropped to approximately $30 \%$ of normotension (13). The blood withdrawal procedure lasted approximately 15-20 min. Hypotension was maintained for $2.5 \mathrm{~h}$. At the end of the normotensive stabilization period and after $2.5 \mathrm{~h}$ of hemorrhagic hypotension, mean values of MABP, Qcar, and ECBA were calculated over $3 \mathrm{~min}$ and cerebral arterial and venous blood samples were obtained to calculate cerebral $\mathrm{O}_{2}$ supply and $\mathrm{O}_{2}$ consumption values and for measurement of the concentrations of NOx in plasma.

Measurements of MABP, Qcar, and ECBA could only be performed in the instrumented lambs. Instrumentation of the siblings was not feasible. CSF was obtained at the end of the hypotensive period. Thereafter, the lambs were killed with an overdose of pentobarbital. Within 5 min, cerebral cortical tissue was obtained. Because the ewes were kept in an optimal ventilatory and circulatory condition until the end of the experiment, we assumed that the siblings were in a normotensive (fetal) situation (8). The glutamate and aspartate concentration in the CSF and the cGMP concentration in brain tissue as well as the MAP2 staining in the siblings were considered to be similar in the instrumented lambs during normotension, if CSF and brain tissue could have been obtained in these lambs during normotension. Therefore, we linked the CSF glutamate, cGMP tissue concentration, and MAP2 staining scores of the siblings to the physiologic normotensive values of the instrumented lambs.

Sampling of body fluids and brain tissue. Blood was obtained from the right brachial artery in the seven instrumented lambs before and after $2.5 \mathrm{~h}$ of hemorrhagic hypotension. CSF was obtained by puncture of the cisterna magna. After anterior flexion of the neck, the needle was introduced through the foramen magnum at a point just below the nuchal ridge until the appearance of CSF. Blood and CSF samples were immediately centrifuged (3000 rpm, $10 \mathrm{~min}$ ) and frozen at $-80^{\circ} \mathrm{C}$ until analysis. From each of the seven instrumented lambs and the seven siblings, one cerebral cortical tissue sample was dissected from the left parasagittal brain, $5 \mathrm{~mm}$ distal from the sutura sagittalis and $2 \mathrm{~mm}$ posterior from the sutura coronalis, adjacent to the EEG electrodes. The samples were coded for blinding purposes. Brain tissue samples were halved for cGMP determination and MAP2 staining. They were immediately frozen in liquid nitrogen and kept in the freezer $\left(-80^{\circ} \mathrm{C}\right)$ until analysis.

NOx determination. Plasma samples from the seven instrumented lambs, before and after $2.5 \mathrm{~h}$ of hemorrhagic hypotension, were used to determine NOx. Nitrates, as end-products of the cerebral nitric oxide production, were reduced to $\mathrm{NO}_{2}$ by spongy cadmium. The sum of the concentrations of $\mathrm{NO}_{2}$ and $\mathrm{NO}_{3}$ (NOx) was measured after using the Griess reagent. OD was read at 540 nm (VersaMax, Molecular Devices, Menlo Park, CA).

Glutamate and aspartate determination. The concentrations of glutamate and aspartate were determined in CSF of the instrumented lambs after $2.5 \mathrm{~h}$ of hemorrhagic hypotension. Concentrations of glutamate and aspartate during normotension were determined in CSF samples of the siblings. Frozen aliquots of the samples were unthawed and immediately deproteinized without dilution by ultrafiltration through Amicon Ultra-4 devices with 10,000 D membrane. The free amino acids were derivatized using Waters AccQ.Fluor reagent kit (Milford, MA). Cysteic acid was used as internal standard. Separation of the derivatives of cysteic acid, aspartate, glutamate, asparagine and glutamine was achieved with Waters HPLC equipment provided with a RP8RP C18 column in a 30-min program. Elution was started with a mixture of $91 \%$ (vol/vol) eluent A (Waters kit) and 9\% (vol/vol) of a $60 \%$ (vol/ $/ \mathrm{vol})$ acetonitrile in water. After $7 \mathrm{~min}$, the ratio was changed to $86: 14 \%$. Fluorometric detection with excitation wavelength of 250 and emission wavelength of $395 \mathrm{~nm}$ took place in a Waters 474 flow cell. Commercially available amino acid mixtures were used for quantification.

cGMP determination. The brain tissue was homogenized in $6 \%$ trichloroacetic acid (TCA). The homogenate was centrifuged for $10 \mathrm{~min}$ at 10,000 $g$. The pellet was washed with TCA, centrifuged again, and the supernatants of both centrifugation steps were pooled. Then, the supernatants were cleared of TCA by a 4-fold wash with water-saturated diethyl ether. The washed supernatants were dried under $\mathrm{N}_{2}$ and stored at $-20^{\circ} \mathrm{C}$. The pellet material was diluted with distilled water and samples were used for the determination of the protein content with the BCA protein assay reagent (Pierce, Rockford, IL).

The cGMP enzyme immunoassay RPN 226 was used for the determination of the cGMP concentration (Amersham Pharmacia Biotech, Little Chalfont, Buckinghamshire, UK) in the distilled water dissolved supernatants of brain tissue. The assay, including the acetylation procedure, was performed as prescribed by the manufacturer. The enzyme reaction was stopped by the addition of sulfuric acid and OD was read at $450 \mathrm{~nm}$.

MAP2 staining. The frozen cerebral cortical tissue samples were cut in slices of $8 \mu \mathrm{m}$. Immunohistochemistry was performed with cross-reactive mouse-anti-MAP2 (Sigma Chemical Co.-Aldrich, Steinheim, Germany), which is specific for all forms of MAP2. Sections were then incubated with horse-anti-mouse-biotin (Vector Laboratories, Burlingame, CA). Visualization was performed using Vectastain ABC (Vector Laboratories). Sections were counterstained with hematoxylin.

The gray matter tissue was scored for positive immunoreactivity. The observer (E.v.d.T.) was blinded to the coding. A three-point score was used, were 1 = optimal positive MAP2 staining (no cerebral cortical tissue damage); 2 = suboptimal positive MAP2 staining (minor cerebral cortical tissue damage); $3=$ no/minimal positive MAP2 staining (extensive cerebral cortical tissue damage and neuronal degeneration) $(11,16,17)$.

Statistical analysis. The mean of left and right hemispheric ECBA was used for further analysis. The Mann-Whitney $U$ test was used to compare values obtained during normotension and after $2.5 \mathrm{~h}$ of hemorrhagic hypotension. The Kruskal-Wallis test was used to compare the three MAP2 score groups. Spearman correlations were used to test the relationship between ECBA and the biochemical parameters. Statistical analysis was performed with the SPSS statistical package (version 12.0, SPSS Inc., Chicago, IL).

\section{RESULTS}

There were no statistically significant differences in birth weight and gender between the instrumented lambs and the siblings.

Table 1 shows the physiologic variables and the CSF excitatory amino acid concentrations during normotensive 
Table 1. Median (range) variables during normotension and after $2.5 \mathrm{~h}$ of hemorrhagic hypotension

\begin{tabular}{lcc}
\hline & $\begin{array}{c}\text { Normotension } \\
(n=7)\end{array}$ & $\begin{array}{c}\text { Hypotension } \\
(n=7)\end{array}$ \\
\hline MABP $(\mathrm{mm} \mathrm{Hg})$ & $62(60-66)$ & $20(13-33) \mathscr{I}$ \\
Qcar $(\mathrm{mL} / \mathrm{min})$ & $24(13-53)$ & $8(2-14) \mathrm{I}$ \\
$\quad \begin{array}{c}\text { Cerebral } \mathrm{O}_{2} \text { supply } \\
\quad\left(\mathrm{mL} \mathrm{O}_{2} / \mathrm{min}\right)\end{array}$ & $3.4(2.1-4.8)$ & $0.3(0.1-1.2) \mathrm{I}$ \\
$\quad \begin{array}{l}\text { Cerebral } \mathrm{O}_{2} \text { consumption } \\
\quad(\mathrm{mL} \mathrm{O} / \mathrm{min})\end{array}$ & $0.9(0.8-1.6)$ & $0.2(0.1-0.3) \S$ \\
Aspartate $(\mu \mathrm{M})$ & $2.9(1.9-6.3)$ & $9.6(3.7-12.8)$ \\
Glutamate $(\mu \mathrm{M})$ & $9.4(2.8-17.1)$ & $21.6(10.3-36.2)^{*}$ \\
ECBA $(\mu \mathrm{V})$ & $8.7(7.5-12.0)$ & $2.9(1.3-7.7) \S$ \\
\hline
\end{tabular}

Mann-Whitney $U$ test compared with normotension.

$* p<0.05 ; \S p<0.005 ; \mathbb{I} p<0.001$.

conditions and after $2.5 \mathrm{~h}$ of hemorrhagic hypotension. After $2.5 \mathrm{~h}$ of hemorrhagic hypotension, MABP, Qcar, cerebral $\mathrm{O}_{2}$ supply, cerebral $\mathrm{O}_{2}$ consumption, and ECBA were significantly lower and the concentration of glutamate was significantly higher compared with the normotensive situation. Four lambs showed extensive cerebral cortical tissue damage, and three lambs showed minor cerebral cortical tissue damage. There was a trend toward higher concentrations of aspartate after $2.5 \mathrm{~h}$ of hemorrhagic hypotension $(p=0.06)$.

Kruskal-Wallis tests showed that cerebral $\mathrm{O}_{2}$ supply was significantly $(p<0.05)$ different between the three MAP2 groups (Fig. 1). Figure 2 shows representative examples of the stained cerebral cortical tissue samples. ECBA differed significantly $(p<0.05)$ between the MAP2 groups; the more neuronal damage, the lower ECBA (Fig. 3). Mann-Whitney $U$ tests showed that the group with no damage was significantly $(p<0.05)$ different from the minor damage group and the minor damage group was significantly $(p<0.05)$ different from the extensive damage group. Glutamate, NOx, and tissue cGMP were higher in the group with extensive damage than in the groups with no damage and minor damage (Fig. 4).

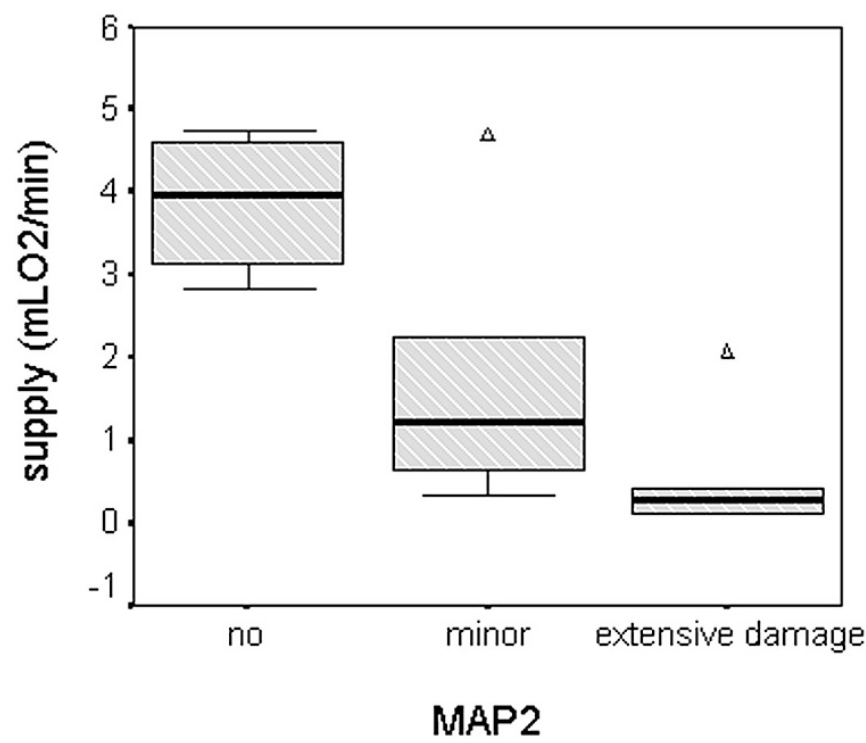

Figure 1. The relationship between no $(n=6)$, minor $(n=4)$, and extensive $(n=4)$ cerebral cortical tissue damage and cerebral $\mathrm{O}_{2}$ supply $(p<0.05)$. Extreme values are represented by $\Delta$.

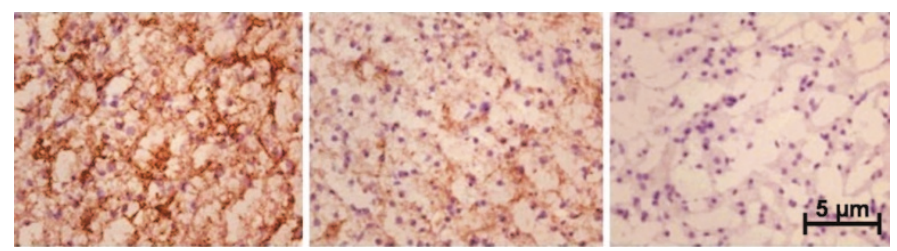

Figure 2. Microscopic images of MAP2 stained frozen $8 \mu \mathrm{m}$ sections of cerebral cortex showing no tissue damage (left), minor damage (middle), and extensive damage (right).

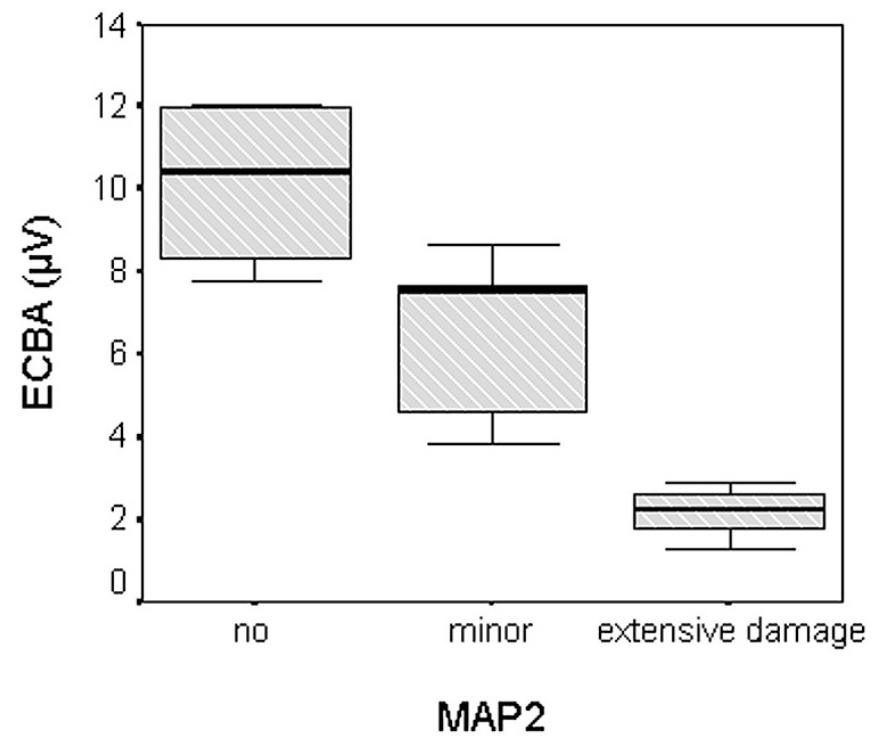

Figure 3. The relationship between no $(n=6)$, minor $(n=4)$, and extensive $(n=4)$ cerebral cortical tissue damage and brain cell function $(p<0.05)$.

Spearman correlation tests showed that ECBA was related to glutamate $(r=-0.95, p=0.000)$, to NOx $(r=-0.90, p=$ $0.000)$, and to cGMP $(r=-0.68, p=0.02)$.

\section{DISCUSSION}

We demonstrated that ECBA is related to the severity of neuronal damage in the underlying cerebral cortex during hemorrhagic hypotension in near-term born lambs. The significant relationships between ECBA and glutamate, NOx, and cGMP suggests that the glutamate, NOx, cGMP pathway plays a role in the pathogenesis of cortical neuronal damage. In the clinical situation, brain injury is a multiplicative effect of the severity of the hypotensive insult and its duration. Due to the design of the study, we can only speculate about the order and the timing of the cascade. A causal relationship between this pathway and cortical neuronal damage was also shown by Van den Tweel et al. (18) and Zhu et al. (19). To test the reversibility of structural and functional neuronal damage was beyond the scope of this study. Furthermore, brain injury is a multiplicative effect of the severity of the hypotensive insult and its duration. Although the influence of time was not specifically addressed in the present study, four out of seven near-term born lambs showed extensive cerebral cortical tissue damage after $2.5 \mathrm{~h}$ of hypotension (30\% of normotensive MABP). In human newborn infants of 26-30 wk gestation a MABP $<30 \mathrm{~mm} \mathrm{Hg}$ for over an hour was associated with severe hemorrhage, ischemic lesions, or death 

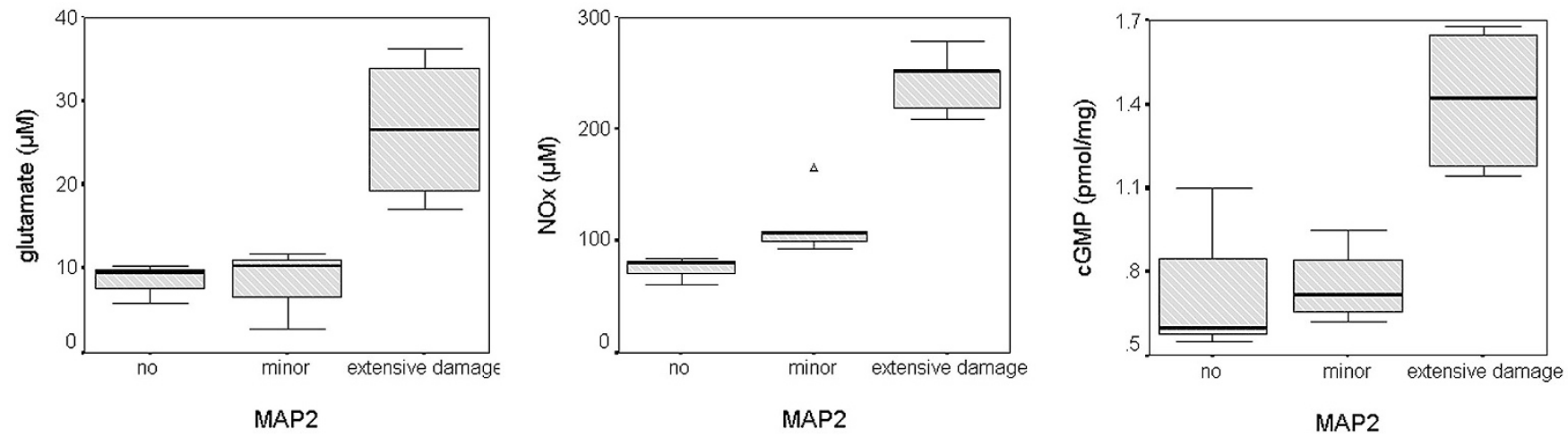

Figure 4. The relationship between no $(n=6)$, minor $(n=4)$, and extensive $(n=4)$ cerebral cortical tissue damage and the concentrations of CSF-glutamate $(p<0.05)$, plasma NOx $(p<0.05)$, and tissue cGMP $(p<0.05)$. Extreme values are represented by $\Delta$.

within $48 \mathrm{~h}$ (20). Note that this study concerns preterm infants, and not near-term born lambs, which were used in the present study.

The near-term born lamb model was chosen to study cerebral cortical tissue damage after $2.5 \mathrm{~h}$ of hemorrhagic hypotension, because the lamb's brain development in the last trimester of pregnancy is rather similar to that in the human fetus (21). Not all organs mature in the same order and with the same speed in the various species. Indeed, the maturational process of the CNS and lungs in lambs occur not in the same way as in the human fetus and infant. In comparison with the human situation, brain maturation is more advanced in the lambs of corresponding gestational age, whereas the lung maturation is slower in lambs. However, the lamb model is applicable in fetal as well as neonatal studies and there is extensive experience with cerebral hemodynamic studies in this animal model $(21,22)$. Furthermore, it is suitable for acute and subacute studies and the size of a near-term lamb is adequate to test and monitor multiple organ systems (22).

Low blood pressure, a common problem in the care for human preterm infants, usually arises from the interplay of ductal shunting, high or low vascular resistance, poor myocardial function, and interaction with positive pressure ventilation, and not only from blood or fluid loss (23). We have chosen to induce hypotension by withdrawal of blood, a method that has been applied by many other research groups to mimic the hypotensive near-term newborn $(24,25)$.

This article shows the results of a relative small number of animals. For ethical reasons, we did not sacrifice more sheep and lambs than absolutely necessary. There was a considerable interanimal variation in the physiologic parameters, which might reflect the variability in maturation and autoregulatory capacities at this stage of fetal development. Despite this variability and the relatively small sample size, we could detect statistically significant decreases in MABP, Qcar, cerebral $\mathrm{O}_{2}$ supply, $\mathrm{O}_{2}$ consumption, and ECBA and a statistically significant increase in glutamate concentrations after $2.5 \mathrm{~h}$ of hemorrhagic hypotension. Furthermore, there was a clear trend toward higher concentrations of aspartate. However, this increase did not reach statistical significance.

Noninvasive recording of electrocortical brain cell activity by means of EEG and CFM-like signals (e.g. ECBA) can be used as a measure for brain cell function in the newborn period (26). Moreover, abnormal tracings are related to neonatal death and in the survivors to impaired neurodevelopmental outcome (27-29). Hellstrom-Westas (30) compared tape-recorded EEG and amplitude-integrated EEG (CFM) in sick newborn infants with gestational ages between 24 and 41 wk. She found a good agreement between these techniques with regard to assessing brain function. Klebermass et al. (31) evaluated the CFM as a tool for neurophysiological surveillance in neonatal intensive care patients. They studied highrisk newborn infants with gestational ages between 25 and 41 wk and found that the correlation between conventional EEG and CFM was $100 \%$.

The cortical brain tissue samples were obtained from a defined area in the left parasagittal cortex, adjacent to the EEG electrodes. Therefore, the results of this study do not provide information about differences between cortical regions and white matter lesions. Sampling of CSF and brain tissue in the instrumented lambs during both the normotensive condition and after $2.5 \mathrm{~h}$ of hemorrhagic hypotension was not feasible. The ewes were monitored continuously and were kept in an optimal ventilatory and circulatory condition and the umbilical cord was not obstructed during the experiments. Since an optimal oxygenation and circulation of the siblings was warranted, we used the CSF and brain tissue of the siblings to determine concentrations of glutamate, aspartate and cGMP, and MAP2 staining during normotension (8). As expected, low glutamate, aspartate, and cGMP concentrations were found in the CSF of the siblings as well as an optimal MAP2 staining. The values of cerebral $\mathrm{O}_{2}$ supply, cerebral $\mathrm{O}_{2}$ consumption, and ECBA during normotension in this study were comparable to values reported previously $(7,8,13)$. Furthermore, the effect of delivery on the physiologic and biochemical parameters is assumed to be negligible after a cesarean section, in particular after a stabilization period of $3 \mathrm{~h}$.

Pettigrew et al. (16) showed in rats that the earliest sign of brain tissue injury could already be detected by MAP2 staining 15 min after focal cerebral ischemia. The loss of MAP2 staining after $2.5 \mathrm{~h}$ of hemorrhagic hypotension in near-term lambs as observed in this study suggests a loss of brain cell (neuronal) integrity leading to a disturbed brain cell function, as shown by ECBA, through mechanisms that very likely involve the glutamate, NO, cGMP pathway. 
Many interconnected pathways are involved in the pathogenesis of perinatal hypoxia-ischemia brain injury, including excessive neuronal $\mathrm{Ca}^{2+}$ influx, overproduction of excitatory amino acids (such as glutamate) and NO release, formation of reactive oxygen species, lipid peroxidation, and induction of cytokine production (32). There is increasing evidence that NO is an important initiator of the neuronal damage following hypoxia-ischemia $(4,33)$.

The main vasoactive effect of $\mathrm{NO}$ is to activate the enzyme sGC and thereby to increase the concentration of cGMP. In turn, cGMP activates cGMP-dependent protein kinases, which can phosphorylate multiple different proteins to induce vascular relaxation (34). cGMP is often used to investigate the NOS/sGC system because of the short half-life of NO (35). In this study, the effect of reduced cerebral $\mathrm{O}_{2}$ supply during hemorrhagic hypotension is still reflected in the NOx concentrations because we have frozen the plasma samples immediately after withdrawal and centrifugation.

During hypotension, vasodilatation occurs in the cerebral circulation, in contrast to the peripheral circulation where vasoconstriction occurs. The concentration of NOx seems to be involved in the mechanisms underlying this coupling between $\mathrm{O}_{2}$ supply and cerebral vascular tone (36). Therefore, the concentrations of NOx in plasma will reflect mainly the cerebral situation. Previously, the concentrations of NOx and cGMP were also determined in the human preterm newborn $(37,38)$. The concentrations of NOx and cGMP were suggested to be related to hypotension and brain damage. In preterm infants with respiratory distress syndrome, a COmediated cGMP increase was found (39). In hypotensive immature lamb, this alternative route mediated by $\mathrm{CO}$ probably does not play a major role, since our results suggest that the concentration of NOx is related to the increase in the concentration of cGMP.

Early recognition of newborns at risk for cerebral damage by means of advanced methods of neuroimaging, combined with a rationale for intervention, may result in the prevention or reduction of lifelong disabilities (40). We conclude that brain cell function can be monitored noninvasively by ECBA and that cortical neuronal damage can be detected after $2.5 \mathrm{~h}$ of hemorrhagic hypotension in the near-term born lamb. The damage is reflected by a reduction of ECBA. The glutamate, NOx, cGMP pathway is likely to be involved in the pathogenesis of cerebral cortical damage. These finding might help to understand the pathology and optimize the treatment of hypotensive human neonates.

Acknowledgments. The authors thank Alex Hanssen, Theo Arts, and Fred Philipsen, Central Animal Laboratory Nijmegen, for their advice and surgical assistance.

\section{REFERENCES}

1. Munro MJ, Walker AM, Barfield CP 2004 Hypotensive extremely low birth weight infants have reduced cerebral blood flow. Pediatrics 114:1591-1596

2. Kume T, Nishikawa H, Taguchi R, Hashino A, Katsuki H, Kaneko S, Minami M, Satoh M, Akaike A 2002 Antagonism of NMDA receptors by sigma receptor ligands attenuates chemical ischemia-induced neuronal death in vitro. Eur J Pharmacol 455:91-100

3. Peeters C, Hoelen D, Groenendaal F, van Bel F, Bar D 2003 Deferoxamine, allopurinol and oxypurinol are not neuroprotective after oxygen/glucose deprivation in an organotypic hippocampal model, lacking functional endothelial cells. Brain Res 963:72-80

4. Dani C, Cecchi A, Bertini G 2004 Role of oxidative stress as physiopathologic factor in the preterm infant. Minerva Pediatr 56:381-394

5. Garthwaite J 1991 Glutamate, nitric oxide and cell-cell signalling in the nervous system. Trends Neurosci 14:60-67

6. Iadecola C 1997 Bright and dark sides of nitric oxide in ischemic brain injury. Trends Neurosci 20:132-139

7. Van Os S, Klaessens J, Hopman J, Liem D, van de Bor M 2003 Preservation of electrocortical brain activity during hypoxemia in preterm lambs. Exp Brain Res 151:54-59

8. Van Os S, De Abreu R, Hopman J, Wethly K, Liem D, van de Bor M 2004 Purine and pyrimidine metabolism and electrocortical brain activity during hypoxemia in near-term lambs. Pediatr Res 55:1018-1025

9. Arnold SE, Trojanowski JQ 1996 Human fetal hippocampal development: II. The neuronal cytoskeleton. J Comp Neurol 367:293-307

10. Johnson GV, Jope RS 1992 The role of microtubule-associated protein 2 (MAP-2) in neuronal growth, plasticity, and degeneration. J Neurosci Res 33:505-512

11. Matesic DF, Lin RC 1994 Microtubule-associated protein 2 as an early indicator of ischemia-induced neurodegeneration in the gerbil forebrain. J Neurochem 63:10121020

12. Tsukidate K, Yamamoto K, Snyder JW, Farber JL 1993 Microtubule antagonists activate programmed cell death (apoptosis) in cultured rat hepatocytes. Am J Pathol 143:918-925

13. Van Os S, Liem D, Hopman J, Klaessens J, van de Bor M 2005 Cerebral $\mathrm{O}_{2}$ supply thresholds for the preservation of electrocortical brain activity during hypotension in near-term born lambs. Pediatr Res 57:358-362

14. Nijland R, Ringnalda B, Jongsma HW, Oeseburg B, Zijlstra WG 1994 Measurement of oxygen saturation by multiwavelength analyzer influenced by interspecies differences. Clin Chem 40:1971

15. van Bel F, Roman C, Klautz RJ, Teitel DF, Rudolph AM 1994 Relationship between brain blood flow and carotid arterial flow in the sheep fetus. Pediatr Res 35:329-333

16. Pettigrew LC, Holtz ML, Craddock SD, Minger SL, Hall N, Geddes JW 1996 Microtubular proteolysis in focal cerebral ischemia. J Cereb Blood Flow Metab 16:1189-1202

17. Schwab M, Antonow-Schlorke I, Kuhn B, Muller T, Schubert H, Walter B, Sliwka U, Nathanielsz PW 2001 Effect of antenatal betamethasone treatment on microtubule-associated proteins MAP1B and MAP2 in fetal sheep. J Physiol 530:497-506

18. van den Tweel ER, van Belz F, Kavelaars A, Peeters-Scholte CM, Haumann J, Nijboer CH, Heijnen CJ, Groenendaal F 2005 Long-term neuroprotection with 2-iminobiotin, an inhibitor of neuronal and inducible nitric oxide synthase, after cerebral hypoxia-ischemia in neonatal rats. J Cereb Blood Flow Metab 25:67-74

19. Zhu C, Wang X, Qiu L, Peeters-Scholte C, Hagberg H, Blomgren K 2004 Nitrosylation precedes caspase-3 activation and translocation of apoptosis-inducing factor in neonatal rat cerebral hypoxia-ischaemia. J Neurochem 90:462-471

20. Miall-Allen VM, De Vries LS, Whitelaw AG 1987 Mean arterial blood pressure and neonatal cerebral lesions. Arch Dis Child 62:1068-1069

21. Raju TN 1992 Some animal models for the study of perinatal asphyxia. Biol Neonate 62:202-214

22. Roohey T, Raju TN, Moustogiannis AN 1997 Animal models for the study of perinatal hypoxic-ischemic encephalopathy: a critical analysis. Early Hum Dev 47:115-146

23. Volpe JJ 2001 Neurology of the newborn. In: Volpe JJ (ed) Neurology of the Newborn. WB Saunders, Philadelphia

24. Ashwal S, Dale PS, Longo LD 1984 Regional cerebral blood flow: studies in the fetal lamb during hypoxia, hypercapnia, acidosis, and hypotension. Pediatr Res 18:1309-1316

25. Pryds A, Tonnesen J, Pryds O, Knudsen GM, Greisen G 2005 Cerebral pressure autoregulation and vasoreactivity in the newborn rat. Pediatr Res 57:294-298

26. Prior P, Maynard D 1979 Monitoring Cerebral Function: Long-term Recordings for Cerebral Electrical Activity. Elsevier/North-Holland Biomedical Press, Amsterdam

27. Connell J, de Vries L, Oozeer R, Regev R, Dubowitz LM, Dubowitz V 1988 Predictive value of early continuous electroencephalogram monitoring in ventilated preterm infants with intraventricular hemorrhage. Pediatrics 82:337-343

28. Thornberg E, Ekstrom-Jodal B 1994 Cerebral function monitoring: a method of predicting outcome in term neonates after severe perinatal asphyxia. Acta Paediatr 83:596-601

29. Toet MC, Hellstrom-Westas L, Groenendaal F, Eken P, de Vries LS 1999 Amplitude integrated EEG 3 and 6 hours after birth in full term neonates with hypoxicischaemic encephalopathy. Arch Dis Child Fetal Neonatal Ed 81:F19-F23

30. Hellstrom-Westas L 1992 Comparison between tape-recorded and amplitudeintegrated EEG monitoring in sick newborn infants. Acta Paediatr 81:812-819

31. Klebermass K, Kuhle S, Kohlhauser-Vollmuth C, Pollak A, Weninger M 2001 Evaluation of the Cerebral Function Monitor as a tool for neurophysiological surveillance in neonatal intensive care patients. Childs Nerv Syst 17:544-550

32. Volpe JJ 2001 Perinatal brain injury: from pathogenesis to neuroprotection. Ment Retard Dev Disabil Res Rev 7:56-64

33. Peeters-Scholte C, Koster J, Veldhuis W, van den Tweel E, Zhu C, Kops N, Blomgren K, Bar D, Buul-Offers S, Hagberg H, Nicolay K, van Bel F, Groenendaal F 2002 Neuroprotection by selective nitric oxide synthase inhibition at 24 hours after perinatal hypoxia-ischemia. Stroke 33:2304-2310

34. Nauli SM, White CR, Hull AD, Pearce WJ 2003 Maturation alters cyclic nucleotide and relaxation responses to nitric oxide donors in ovine cerebral arteries. Biol Neonate 83:123-135 
35. Fedele E, Raiteri M 1999 In vivo studies of the cerebral glutamate receptor/NO/ cGMP pathway. Prog Neurobiol 58:89-120

36. Iadecola C, Pelligrino DA, Moskowitz MA, Lassen NA 1994 Nitric oxide synthase inhibition and cerebrovascular regulation. J Cereb Blood Flow Metab 14:175192

37. Krediet TG, Valk L, Hempenius I, Egberts J, van Bel F 2002 Nitric oxide production and plasma cyclic guanosine monophosphate in premature infants with respiratory distress syndrome. Biol Neonate 82:150-154
38. van Bel F, Valk L, Uiterwaal CS, Egberts J, Krediet TG 2002 Plasma guanosine $3^{\prime}, 5^{\prime}$-cyclic monophosphate and severity of peri/intraventricular haemorrhage in the preterm newborn. Acta Paediatr 91:434-439

39. van Bel F, Latour V, Vreman HJ, Wong RJ, Stevenson DK, Steendijk P, Egberts J, Krediet TG 2005 Is carbon monoxide-mediated cyclic guanosine monophosphate production responsible for low blood pressure in neonatal respiratory distress syndrome? J Appl Physiol 98:1044-1049

40. Ferriero DM 2004 Neonatal brain injury. N Engl J Med. 351:1985-1995 